Greta Goetz

University of Belgrade

Faculty of Philology
14:929 Петронијевић Б.

52:929 Миланковић М.

https://doi.org/10.18485/climb.2017.5.2.ch11

\title{
LITERARY LESSONS IN BRANISLAV PETRONIJEVIĆ AND MILUTIN MILANKOVIĆ
}

\section{Summary}

This paper takes as its Ansatzpunkt, or point of departure, a line from Goethe's Faust - a play that features significantly in the personal writings of both Branislav Petronijević and Milutin Milanković. The line, reworked by Petronijević to read, "enjoyment is common, the deed is all, glory - nothing", is considered first in terms of its original iteration and context in Faust and then in the context of Petronijevićs writing, and ultimately in terms of the holistic intercultural implications of the literary work done by Petronijević and Milanković, which elucidates not just the nuances of science and/ or literature, but also philosophy and even metaphysics. The paper considers how the literary features of Petronijević's and Milanković's work are of pedagogical significance in the "two cultures" debate that began with Thomas Huxley and is ongoing.

Key words: Petronijević, Milanković, Goethe, Faust, Science, Literature, Intercultural fluency, Ansatzpunkt

Let us begin with a picture: of Branislav Petronijević in his university building room, surrounded by books, reading German and English editions of Shakespeare's Hamlet simultaneously. It is thus that he is described by Milutin Milanković, who himself carried around a miniature volume of Goethe's Faust in his pocket at all times, but who nonetheless wrote that Petronijević knew Faust better than he. ${ }^{1}$ This is an important picture for several reasons. First, it shows the extent of the intercultural

1 Milan Milanković, Uspomene, doživljaji, i saznanja, Beograd: Zavod za udjbenike, 2009, 915-916. 
fluency of early $20^{\text {th }}$ century Serbian intellectuals - important to remember in relation to the propaganda presenting Serbians as anti-Western that was spread during the closing decade of that same century. Second, and specifically relevant to the theme uniting this volume of papers, is the fact that entwined in these scientists' thought were lines and motifs from belles lettres. This was not uncommon among the scientists of the $19^{\text {th }}$ and early $20^{\text {th }}$ century, but, if contemporary Western narratives of science and literature are to be believed, this has become uncommon among scientists of the modern age.

The modern dichotomy between literature and science is an almost hackneyed history in the West: beginning with Thomas Huxley's speech "Science and Culture", 2 which ushered in undergraduate teaching in the sciences now stripped bare of the quondam educational foundation in the classics, through Matthew Arnold's rebuttal to that speech, his Rede Lecture at Cambridge entitled "Literature and Science", in which he expands the definition of the belles lettres to include what could be termed literary scientific texts, ${ }^{3}$ through C. P. Snow's "Two Cultures", which presents literature and science as foreign but necessary to each other. ${ }^{4}$ Many humanists continue along these lines of division to this day, rallying a defense of the humanities in the face of university funding cuts. ${ }^{5}$ One such plea is in-

2 Thomas Huxley, "Science and Culture", Science and Culture and Other Essays, New York: D. Appleton and Company, 1888, https://archive.org/details/sciencecultureot00huxluoft, 7-30.

3 "... all learning is scientific which is systematically laid out and followed up to its original sources, and that a genuine humanism is scientific", Matthew Arnold, "Literature and Science", The Nineteenth Century, 12 (August 1882), http://aleph0.clarku.edu/huxley/ comm/19th/Arnold.html, 216-230.

4 C. P. Snow, "The Two Cultures", New Statesman, 6 October 1956, 413-414, http://www. newstatesman.com/cultural-capital/2013/01/c-p-snow-two-cultures.

5 Literature that rallies in defense of the humanities can be found by even the most cursory internet search for that very term, defense of the humanities. One of the most famous is Leon Wieseltier's Brandeis commencement address, published as "Perhaps Culture is Now the Counterculture", New Republic, May 28, 2013, https://newrepublic.com/article/113299/ leon-wieseltier-commencement-speech-brandeis-university-2013. Other notable works include William Deresiewicz's Excellent Sheep: The Miseducation of the American Elite, New York, Tokyo, London: Free Press, 2015, Irving Babbitt and Kirk Russell's Literature and the American College: essays in defense of the humanities, Washington D.C.: National Humanities Institute, 1986, https://archive.org/details/literatureandam02babbgoog, Martha C. Nussbaum's Why Democracy Needs the Humanities, Princeton: Princeton University Press, 2016, and Adam Gopnik's relatively comprehensive overview, "Why Teach English?", The New Yorker, August 27, 2013, https://www.newyorker.com/books/ 
teresting for having been published by a professor of chemistry and biochemistry, Gregory Petsko, to protest the closure of humanities programs, entitled, "A Faustian Bargain". In his essay, he calls on the etymology of university, which derives from "the whole", and argues "Goethe believed that it profits a man nothing to give up his soul for the whole world." ${ }^{6}$ This paper will also focus on Goethe's Faust, given that Milanković claimed to have carried it with him wherever he went and because it is cited so much by Petronijević.

This paper takes as its point of departure ${ }^{7}$ the oft-quoted line that is central to an understanding of Faust, "Fame is nothing! The deed is all!", a line which Petronijević reworks in one of his letters. ${ }^{8}$ Faust, who we see at the beginning of the play overcome by a temporary despair that fulfillment cannot be found in great deeds or actions, or in the value of science, makes a pact with Mephistopheles. But Mephistopheles misjudges him, as Faust ultimately comes to value the significance of the deed far above the vanity, egotism, and pleasure-seeking that Mephistopheles thought he would succumb to. Thence the significance of the line, "Fame is nothing! The deed is all!" Before exploring Petronijevićs reworking of the line, we shall remain with its original context in Faust in order to make a point about literature.

It has been argued that those words contain the denouement of the play, and that they are related to the words - also about the "all" that contain the play's turning point: "In thy Naught I hope to find the All". Faust now sees that the All lies in what is nothing for Mephistophe-

page-turner/why-teach-english.

6 Specifically, the French, Italian, classics, Russian, and theater programs at SUNY, Albany. Gregory A. Petsko, "A Faustian Bargain: An open letter to George M Philip, President of the State University of New York at Albany", 31 October 2010, https://genomebiology. biomedcentral.com/articles/10.1186/gb-2010-11-10-138. Petsko teaches at Brandeis.

7 Or, handle by which an understanding of these thinkers may be seized, as per Auerbach's methodology: "in order to accomplish a major work of synthesis it is imperative to locate the point of departure [Ansatzpunkt], a handle, as it were, by which the subject can be seized. The point of departure must be the election of a firmly circumscribed, easily comprehensible set of phenomena whose interpretation is a radiation out from them and which orders and interprets a greater region than they themselves occupy." Erich Auerbach, "Philology and 'Weltliteratur,"' trans. E. and M. Said, The Centennial Review, Vol. 13, No. 1 (Winter 1969), 13-14.

8 Branislav Petronijević, Autobiografija, pesme, prepiska, Beograd: Zavod za udjbenike i nastavna sredstva, 1998, 124-5. 
les, which is to say that the All lies in creative energy. A devout choir sang about this creative energy at the opening of the play, which begins at Easter: "The buried One ... In the joy of becoming, He is near creative bliss". 9 These lines reveal Goethe's morphological scientific method, according to which the All is connected to the creative energy that effects change upon every living being. Faust, by aligning himself with creative energy, demonstrates an Aristotelian truth, "that man's salvation lies not in pleasure or wealth or position or fame, but in rational, self-determined action, pure $\varepsilon v \varepsilon \dot{\rho} ү \varepsilon \alpha^{\prime \prime} .{ }^{10}$ For the initiate, Goethe's play communicates the ineffable Urphänomene (which is to say, the underlying pattern of what is or what must become), not through argument but through the feelings evoked by dra$m a$, intuited morphologically. "When, having something before me that has grown," Goethe writes, "I inquire after its genesis and measure the process as far back as I can, I become aware of a series of stages, which, though I cannot actually see them in succession, I can present to myself in memory as a kind of ideal whole". ${ }^{11}$ The underlying pattern of what must become in Faust is the saving grace of the deed, together with prayer and also the parameters of time and space not as limitations but as preconditions that make human deeds possible. As such, Faust is as much about science, moral philosophy, and metaphysics than it is about literature.

Literature - obviously where it includes Goethe's works, but also the poems of Alexander Pope, and especially if it is to be inclusive enough as to encompass the Lucretius' On the Nature of the Universe or Francis Bacon's The New Atlantis - may require knowledge of science, philosophy, and metaphysics if it is to be more deeply understood. This paper began with the image of Petronijevic poring over Shakespeare: who would expect this image of a scientist cultivating his knowledge of literature, and how many students, even of philology, today spend their own time in this way? But more telling of this image is Petronijević as an initiate of liter-

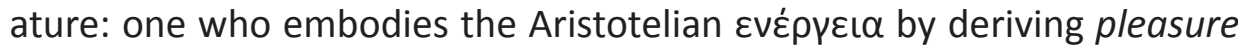
from the work, or deed, of reading all sorts of literature, including that which questions the motives behind actions.

9 Thomas Davidson, The Philosophy of Goethe's Faust, Boston, New York: Ginn \& Company, 1906, https://archive.org/details/philosophyofgoet00davirich, 130. Ibid.

Johann Wolfgang von Goethe, Goethe on Science: A Selection of Goethe's Writings, ed. Jeremy Naydler, Edinburgh, Floris Books, 1996, 119. 
Let us now turn to the Faustian lines that he reworked. Goethe's original reads: "Die (dee) Tat ist alles, nichts der Ruhm. ... Genießen macht gemein (ge knee sen macht ge mine)". Petronijević writes the lines in a different order, "Genießen ist gemein, / Die tat ist alles, / Der Rhum nichts", in this way, and in the style of a true logician, he formulates them into a logical whole, also making another small change. His version reads: "enjoyment is common [instead of enjoyment makes one common],/ the deed is all,/ glory - nothing".

There is much here to ponder in three lines - the first being the fact that instead of merely quoting lines, Petronijević reworks them, which is a good, classical technique that students should keep in mind (for even the earliest rhetorical exercises of the progymnasmata require some aspect of invention - not just through variation but amplification, addition, subtraction, transposition, substitution, etc.) This aspect of writing seems lost on many young writers, who are sadly taught to find their inner muse without first being exposed to the fragments of antiquity as playthings for a more fertile imagination. Petronijević shows that assimilating the corpus of classical literature is so far from dogmatic as to actually be empowering: enabling writers to adapt it to fit the purpose at hand.

The purpose at hand in which he quotes these lines from Faust is to encourage Jovan Hadji Vasiljević in his work. Enjoyment is common he begins, and indeed it is, who would deny that? But to read the lines as they appear in Goethe (albeit the line "for pleasure common makes" appears lower down, in a different verse), enjoyment seems to be contrast-

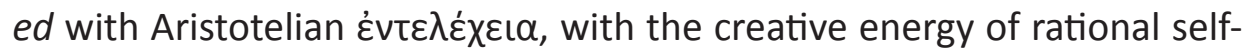
determined action that implies the work of the actuality of the fulfillment of potentiality. In Goethe, we must agree that above and detached from the enjoyment of pleasure is the kind of work that brings self-fulfillment. But in Petronijević, while the deed also reigns supreme, pleasure is acknowledged as a common denominator: the feeling behind his reworking is more merciful.

To think of the three lines "enjoyment is common,/the deed is all,/ glory - nothing" within the context of Faust and then to consider them within the context of that letter, they become more profound.

In the play, at the time Faust speaks these three lines, he is beginning to realize that he had been deceived, though he is not strong enough 
to regain control of his life. We remember the terrible trials Faust went through as a dissatisfied, disillusioned older scholar - which anyone reading a paper such as this could turn into or already be. Because of his unhappiness, he was tempted by Mephistopheles to make a deal to exchange his soul for all he thought he wanted. The three lines, as they appear in Faust, together form grave advice. To follow it is to be spared of what Faust was not: spared, for example, of a love who goes mad and kills her own child. The lines also recalls the Deed with Mephistopheles that is a deed contracted in time, which brings Faust into a destructive act that ultimately saves him from his initial despair by ruining all he had known.

But the lines, "Enjoyment is common, the deed is all, glory - nothing" are spared of the tragedy; what is left is a most gentle invitation to creation for the love of it. Work rises up from the basis of an enjoyment acknowledged as universal. To depart from enjoyment into meaning is to create, so the accent here is on not being passive.

The line that Petronijević quotes most often in his letters is also from Act II of Faust: "Das ist der Weisheit letzter Schluß", and means, "The last word Wisdom ever has to say". He uses this line (together with another of Goethe's that he reworked, though keeping Goethe's rhyming scheme) to emphasize his belief in one of his theories, specifically, how the solution of all world problems lies within the dynamic theory of matter. ${ }^{12}$ In another letter, also to Milan Šević, he uses it to underline the certainty of his ideas. Then he goes on to explain how from certainty he has gone to the other extreme where his sight is blocked by a rock he cannot move, which he hopes will stand for something, and prays for God's mercy that he might receive the Holy Spirit to enlighten him so that he may lift up that rock, and see what lies behind it. ${ }^{13}$ In addition to metaphysical themes, this passage also contains cognitive-metaphorical ones. Much has been written of the use of the metaphor in the explanation of scientific ideas, in fact, another Serbian scientist, Mihajilo Petrović-Alas has written extensively on this subject. ${ }^{14}$

12 Petronijević, 129.

13 Ibid, 132.

14 Mihailo Petrović, Metafore i alegorija, Beograd: Zavod za udjbenije i nastavna sredstva, 1997; La Mécanique des Phénomènes fondée sur les Analogies, Paris:Gauthier-Villars, 1906. 
But here, we will remain with Petronijevićs Faustian adaptations: after his metaphor of the rock, he writes, "Mir hilft der Geist! Ich finde Rath/ Und hinter Steine Schau No-That". In other words, "Help me, spirit! I find counsel/ and behind the rock is revealed - nothing." From Faust are taken the first four words in the first line and the last in both lines; the rest is Petronijevićs own improvisation. It is noted that he always observes a rhyme scheme. The original first line is: "Mir hilft der Geist! Auf einmal seh ich Rat" - meaning, "The spirit help me! I have it now, intact". The second line ends with a half-English, half-German neologism, "No-That", meaning "deedless", i.e., "nothing". These lines are followed by continued prayer that he at least remain humane, hopefully also in politics, and then he changes tone, shifting from his humorous approach to serious matters to complete gravity, all while continuing to demonstrate his fluency in a variety of rhetorical techniques:

Up until now I have been speaking seriously in unserious 'accentuations' and now I will not speak otherwise, but will speak seriously seriously (because precisely in such a way will the dual extremism be pronounced: because first it is like this $X$ and then like that - ).

This sentence is a clever example of a chiasmus, showing yet again that this scientist has access to the fineries of the flowers of speech, and is not limited to the cold rationalist, utilitarian scientistic discourse we might expect. The fun aspect of Petronijević's chiasmus is that it literally has an " $X$ " in it.

Milanković also used figures of speech in his writing; I will focus on two related sections of his autobiography that are about the body. This example was chosen because it is developed following one of the opening chapters, entitled "Fabrički misli" ("Thought Factory"), in which he begins with Lamettrie's metaphor of a machine to describe man in order to develop his own metaphor, of the human mind as a factory. ${ }^{15}$ He writes that his heart insists that he explore his mind, ${ }^{16}$ and ends the chapter explaining that it is precisely in his mind where the archive of his earliest memories can be found. ${ }^{17}$ This chapter leads into the chapter entitled "Prve uspomene" ("First Memories"). He humorously suggests that he use a

15 Milanković, 83.

16 Ibid, 84.

17 Ibid, 88. 
Baedeker ${ }^{18}$ - the eloquent guide book series that was immensely popular in Victorian times - in order to explore the anatomy and physiology of his mind. Here, figures of speech are embedded on a compositional level: the introduction to his earliest memories is a chapter on the factory that produces thought to begin with.

It should be noted here that one of the preoccupations of Charles Dickens in his periodicals Household Words, All the Year Round, and The Small Beer Chronicles, was to present science in an interesting way, instructing his writers to integrate new scientific discoveries they learned of from lectures given by famous scientists into the short stories they were assigned to write. Leigh Hunt wrote many of these stories, with titles like "The Chemistry of a Candle". They were rather strained attempts at prose, with awkward older characters asking younger ones how certain things work.

In this context, then, Milanković's chapter "Thought Factory" is a most humorous introduction to the subsequent chapter, "First Memories". As he writes later chapters, Goethe and his works accompanied his growth. Chapter 21 opens with him explaining how, by writing about his childhood, he felt like he was reliving it, though not so much with enjoyment but more like how Goethe felt on his return to Italy. ${ }^{19} \mathrm{He}$ recounts in "At a Crossroads" 20 how he read Goethe's The Stories of Young Werther and Faust as well as the dramas of Schiller and Shakespeare, "living in a world of poetic creation". ${ }^{21}$ In the chapter entitled "New Perspectives" ("Novi vidici"), he describes how a key moment in his development occurred when he read Georg Brandes' William Shakespeare: A Critical Study. As if he were a philologist, he writes of his joy over the fact that Brandes cited the same German translation of Shakespeare (by Schiller) that he himself had read. He felt conflicted about being a mathematician and studying cold engineering when it was not for him a spiritual food. ${ }^{22}$ He then decided to institute a new regime of study, wherein he was to devote part of his time to study of the arts. ${ }^{23}$ He put aside an hour or two a




day towards reading literature - which was perhaps a mature iteration of his childhood pastime of using a book to track butterflies. ${ }^{24}$

Later, he writes that he never understood his brain scientifically, and worried that he never studied philosophy or logic. He explains that he consoled himself by reading the passage in Faust where Mephistopheles teaches his student about logic. He would also remind himself that he had never actually had to pay the price for lacking such knowledge. He quotes Goethe: "ich hab' es klug gemacht:/ Ich habe nie über des Denken gedacht". In other words: "I have behaved very cleverly - I have never thought about thinking." Milanković notes that he explained the development of his spiritual development in earlier chapters. ${ }^{25}$ His use of the word "spiritual" seems primarily to reference to an understanding of the arts, though among the arts are included religious hymns ${ }^{26}$ and spiritual contemplation. ${ }^{27}$ Milanković did not write about metaphysics in a narrow or even Aristotelian sense: Aristotle himself did not know the word metaphysics, but in the book that later became known as his Metaphys-


tral to Faust. Yet we have seen how Faust, the work Milanković carried on his person, communicated metaphysical ideas - if not through argument but through the feelings evoked by drama. Perhaps that by worrying over a lack of logic and philosophy - and we might add, by extension the science that is to follow them, metaphysics - it is nonetheless being engaged with, on some level. This will be illustrated by way of the contrast that follows.

In C. P. Snow's famous work on the divide between science and literature, "Two Cultures", he notes that modern-day scientists have a disdain for philosophy and especially metaphysics, despite having once traditionally engaged with both, while humanists are no longer literate in basic scientific texts and principles. He writes that: "Not to have read War and Peace and La Cousine Bette and La Chartreuse de Parme is not to be educated; but so is not to have a glimmer of the Second Law of Thermodynamics." What the examples from the works of Petronijević and Milanković 
taken as the point of departure for this paper show is that these scientists united both cultures within themselves, if at the very least, as in the case of Milanković, where philosophical ideas take on a literary form. Neither Petronijević nor Milanković subscribe to the ideological total claim of the new scientific method to dominate the entire field of human knowledge. ${ }^{28}$ The picture of Petronijević sitting down comparing Shakespeare's Hamlet - or, as Milanković saw him do - compare Goethe's Faust with piles of books of commentary, demonstrates this. Milanković seeking spiritual food in devoting time to the arts is another illustration. He also hints at a more universal direction of thought when he writes about how as a boy, he had been conflicted by an adult saying to him that God is nature. "Little pantheists don't ask the question, 'So what is nature?'"29 The hint is towards the larger questions of existence, towards universals, which is where connections can be made. Milanković may have being pursuing metaphysical questions throughout his life more than he was aware of.

Huxley, in his speech that led to the abolishment of mandatory university study of the classics, claims that "an exclusively scientific training will bring about a mental twist" 30 - ostensibly arguing that the questions raised by the humanities are essential to a healthy human mind. But knowing how he approached issues elsewhere, such as in the opening issue of Nature magazine, ${ }^{31}$ or the fact that he coined the word ag-

28 See Paul Ricoeur, "Science and Ideology", From Text to Action: Essays in Hermeneutics, II, trans. Katherine Blarney and John B. Thompson, Evanston: Northwestern University Press, 1991, 246-269.

29 Milanković, 131.

30 Huxley, "Science and Culture".

31 Huxley's introduction to Nature, prefaced by the aphorisms of Goethe, disregards the Goethe's classical references of how nature is "always veiled": "No more fitting preface could be put before a journal, which aims to mirror the progress of that fashioning by Nature of a picture of herself, in the mind of man, which we call the progress of science" (emphasis added). Huxley makes it clear that it is not the aphorisms that are "fitting", but Goethe's later assessment of his aphorisms, written over forty years later-in 1828, when he altered the view he had taken in the aphorisms: "If we consider the high achievements by which all the phenomena of Nature have been gradually linked together in the human mind [since the aphorisms were written]; and then, once more, thoughtfully peruse the above essay[i.e. the aphorisms], from which we started, we shall, not without a smile, compare that comparative, as I called it, with the superlative which we have now reached, and rejoice in the progress of fifty years" (emphasis 
nostic, this claim can be doubted. First, he was impatient for the development of science that would herald industrial progress. Second, one of the jabs in his speech was, "A man may be a better scholar than Erasmus, and know no more of the chief causes of the present intellectual [scientific] fermentation than Erasmus did". ${ }^{32}$ That type of critique is addressed in many works that aim to defend the humanities. For example, Isaiah Berlin argues that the humanities are a different type of learning. ${ }^{33}$ Paul Ricoeur writes of the temptation of the total truth claims proffered by science. ${ }^{34}$ Goethe presents a Faust yearning for change and to live in the ideal instead of living in everyday reality with its [human - and humanistic?] good and bad mixed together - and reveals the tragedy of this. We know that Petronijević and Milanković sought knowledge that was not only scientific and have seen in this paper how they seemed to live in accordance with the humanistic pursuit; the dichotomy of two cultures does not exist for them. Nor does it for Goethe. They all shared in common avid reading habits and an actualization - through intercultural fluency - of the successful operation of man's innate nature as homo faber ${ }^{35}$

added). Huxley concludes that the science being propagated by the magazine will one day become obsolete, though Goethe's poetic vision will remain: "When another half-century has passed, curious readers of the back numbers of NATURE will probably look on our best, 'not without a smile;' and, it may be, that long after the theories of the philosophers whose achievements are recorded in these pages, are obsolete, the vision of the poet will remain as a truthful and efficient symbol of the wonder and the mystery of Nature." Goethe and Huxley criticize the aphorisms for their pantheistic tone-and it is through such literary examples that the rift between scientific and metaphysical views begins to emerge. While the inclusion of aphorisms in a scientific publication underlines the cross-cultural fluency manifest in the periodicals of the $19^{\text {th }}$ century, and represents the classical training of Nature's founders, Huxley and John Tyndall, it was short lived. Thomas Huxley, "Goethe: Aphorisms on Nature", Nature, No. 1 (November 4, 1869), http://www.nature.com/nature/about/first/. Huxley, "Science and Culture".

Isaiah Berlin, The Proper Study of Mankind, edited by Henry Hardy and Roger Hausheer, New York: Farrar, Straus and Giroux, 1997.

34 Ricoeur, 246-269.

35 i.e., within the parameters of (philosophical) teleological development where a move towards perfection can be reached through the virtuous actions stemming from the discovery of right and wrong through speech and reason. The "literary lesson" taught by Petronijević and Milanković is that this is discovered through the literary, wherein literature includes scientific writings as well as belles lettres and philosophy, etc. 
We shall end with an image of Petronijević. According to Milanković, Petronijević spent every last penny on books, and lived in penury - like Erasmus did, we might add, in his day. In the culture of today, obsessed with material wealth and the rise of science over the humanities, how many would live along Petronijević's lines?

\section{Bibliography}

Arnold, Matthew Arnold. "Literature and Science", The Nineteenth Century, 12 (August 1882). 216-230, http://aleph0.clarku.edu/huxley/comm/19th/Arnold.html.

Auerbach, Erich. "Philology and 'Weltliteratur."' Trans. E. and M. Said. The Centennial Review, Vol. 13, No. 1 (Winter 1969).

Babbitt, Irving and Kirk Russell. Literature and the American College: essays in defense of the humanities. Washington D.C.: National Humanities Institute, 1986. https://archive.org/details/literatureandam02babbgoog.

Berlin, Isaiah. The Proper Study of Mankind. Edited by Henry Hardy and Roger Hausheer. New York: Farrar, Straus and Giroux, 1997.

Davidson, Thomas. The Philosophy of Goethe's Faust. Boston, New York: Ginn \& Company, 1906. https://archive.org/details/philosophyofgoet00davirich.

Deresiewicz, William. Excellent Sheep: The Miseducation of the American Elite. New York, Tokyo, London: Free Press, 2015.

Goethe, Johann Wolfgang. Goethe on Science: A Selection of Goethe's Writings, ed. Jeremy Naydler, Edinburgh, Floris Books, 1996.

Gopnik, Adam. "Why Teach English?" The New Yorker (August 27, 2013). https://www. newyorker.com/books/page-turner/why-teach-english.

Huxley, Thomas. "Goethe: Aphorisms on Nature." Nature, No. 1 (November 4, 1869). http://www.nature.com/nature/about/first/.

------ . Science and Culture and Other Essays. New York: D. Appleton and Company, 1888. https://archive.org/details/sciencecultureot00huxluoft.

Milanković, Milan. Uspomene, doživljaji, i saznanja. Beograd: Zavod za udjbenike, 2009.

Nussbaum, Martha C. Why Democracy Needs the Humanities. Princeton: Princeton University Press, 2016.

Petronijevć, Branislav. Autobiografija, pesme, prepiska. Beograd: Zavod za udjbenike i nastavna sredstva, 1998.

Petrović, Mihailo. Metafore i alegorija, Beograd: Zavod za udjbenije i nastavna sredstva, 1997.

------ . La Mécanique des Phénomènes fondée sur les Analogies, Paris:Gauthier-Villars, 1906.

Ricoeur, Paul. From Text to Action: Essays in Hermeneutics, II. Trans. Katherine Blarney and John B. Thompson. Evanston: Northwestern University Press, 1991.

Snow, C. P. “The Two Cultures", New Statesman (6 October, 1956), 413-414. http://www. 
Култура и/или наука

newstatesman.com/cultural-capital/2013/01/c-p-snow-two-cultures.

Wieseltier, Leon. "Perhaps Culture is Now the Counterculture", New Republic (May 28, 2013). https://newrepublic.com/article/113299/leon-wieseltier-commencement-speech-brandeis-university-2013.

\author{
Грета Гец \\ Универзитет у Београду \\ Филолошки факултет
}

\title{
ЛЕКЦИЈЕ ИЗ КЊИЖЕВНОСТИ О БРАНИСЛАВУ ПЕТРОНИЈЕВИЋУ И МИЛУТИНУ МИЛАНКОВИЋУ
}

\section{Сажетак}

Ослањајући се на аспекте Викоове филолошке књижевне критике код Ериха Ауербаха, које је Ајзаја Берлин подржао као оне који истичу прожимање науке и хуманистике, овај рад ће узети у разматрање књижевне фрагменте (онога што је Ауербах назвао „Ansatz“) признатих српских научника 20. века Бранислава Петронијевића и Милутина Миланковића. Оба ова научника су трагала за облицима знања који излазе из оквира науке, што је на појединим местима изражено кроз креативна књижевна решења, понекад се позивајући на Гетеовог Фауста. Читање ненаучних радова Петронијевића и Миланковића нас подсећа на фаустовску параболу и на оно што Берлин препознаје као забринутост, која је типучна за Викоа и Ауербаха: наиме, да потрага за знањем награђује посматрача самосвешћу да препозна у шта се верује или по којим принципима се живи, као и да се игнорисањем овога у корист идеолошке свеукупне потраге за новим научним методом који би доминирао читавим пољем људског знања пристаје на илузију; или намерно незнање. Наука као идеологија, како је то Пол Рикер објаснио, налаже да човек живи у идеалној визији (као да је то могуће), а не да живи у складу са њом, да се надовежемо на фразу Хермана Рендала која је посебно прикладна данас.

Кључне речи: Бранислав Петронијевић, Милутин Миланковић, наука, књижевна решења, херменеутика, филологија, идеологија 